\title{
FOREIGN ENTRY MODES UNDER INSTITUTIONAL PRESSURES: THE IMPACT OF STRATEGIC RESOURCE SEEKING AND MARKET SEEKING STRATEGIES
}

\author{
Manuel Portugal Ferreira' \\ Fernando Antonio Ribeiro Serra ${ }^{2}$
}

\begin{abstract}
Multinational corporations (MNCs) are subject to the various dimensions of the external institutional environments. Institutional theory suggests that MNCs need to conform to the prevailing rules, norms and procedures of the locations where they operate in order to survive and grow. This means that MNCs need to develop the best possible configuration of strategy-structure for their worldwide operations. Previous research has noted that in these conditions firms may simply seek to follow a referent other. However, MNCs' specific strategy for a focal foreign operation is likely to determine the entry mode for each host country. In certain circumstances it may be whether MNCs are pursuing a market-seeking strategy or a strategic resource seeking strategy that shapes the entry mode in face of the prevailing institutional pressures. We contribute to the understanding of entry modes into foreign markets as a reflection of a strategic choice that is bound by institutional constraints.
\end{abstract}

Keywords: Multinational corporations; institutional theory; foreign entry modes.

\section{INTRODUCTION}

To survive and grow in their operations multinational corporations (MNCs) need to balance internal and external institutional pressures (DiMaggio \& Powell, 1983). These pressures emanate from both the internal to the firm, and the home and the foreign (or host) business environments. In multi-divisional firms, such as MNCs,

\footnotetext{
' Doutor em Business Administration pela Universidade de Utah, EUA. Professor Coordenador do Instituto Politécnico de Leiria. Professor visitante da Unisul Business School, Director do globADVANTAGE - Center of Research in International Business \& Strategy. Endereço: Escola Superior de Tecnologia e Gestão, Instituto Politécnico de Leiria, Morro do Lena - Alto Vieiro, 24l I -9 I I, Leiria, Portugal. E-mail: portugal@estg.ipleiria.pt.

2 Doutor em Engenharia pela Pontifícia Universidade Católica do Rio de Janeiro - PUC/RJ. Coordenador da Unisul Business School e Professor do Mestrado em Administração da Universidade do Sul de Santa Catarina. Endereço: Rua Trajano, 219, Centro, Florianópolis, SC. CEP 88010-010. E-mail: fernando.serra@unisul.br. Membro efectivo do globADVANTAGE - Center of Research in International Business \& Strategy. Artigo recebido em: 04/0 I/2008. Aceito em: 26/I 0/2008. Membro do Corpo Editorial Científico responsável pelo processo editorial: Rolando Juan Soliz Estrada.
} 
the need to adjust to the internal pressures may be far more complex than in single business firms, given that the pressures emanate from both the headquarters and from other subsidiaries dispersed throughout the world. The host demands means that the structure and internal procedures of the MNCs' subsidiaries need to be adjusted to the expectations and requirements imposed by the agents in the host countries. That is, they are at best complementary to the home country-based pressures, such as those by suppliers, clients, banks, industry and trade associations, and so forth. Nonetheless, in some instances, the foreign and the home pressures may be conflicting and adaptation may be hazardous. In sum, adjusting to the institutional environments is a condition for survival in the first stance and for growth.

To survive and prosper in their foreign operations, MNCs need to balance several, and often conflicting tensions. The MNCs try to overcome the hazards of operating in foreign markets by mimicry of incumbent firms, adopting similar practices, procedures and structures. Hence, we refer that the institutional pressures lead firms towards homophily. Recently some scholars argued that both environments and firms co-evolve (NELSON; WINTER, 1982; MCKELVEY, 1997) and that firms may have different strategies (e.g., foreign entry modes) even when they are subject to seemingly overwhelming pressures for conformity. The international business research has mainly assumed that these pressures stem only from the foreign host country, but this is not the sole case (KANTER, 1997) since the foreign subsidiaries of the MNCs also need an internal license to operate, which takes them to resemble each other.

The extant research in international business studies has delved into many strategic dimensions but has more rarely focused specifically on the institutional and social context in which entry strategies are selected. Notwithstanding, Ellis (2000) observed how inter-firm ties facilitated the identification of export opportunities. Henisz (2000) focused on the institutional environments (specifically, on the political hazards) of the host countries and how the environment influences MNCs' operations. Xu and Shenkar (2002) proposed a series of relationships regarding institutional distance and the choice of locations and foreign entry modes. Kostova \& Zaheer (1999) examined the institutional environment in which intra-MNC (intersubsidiaries) transfers of best practices occurred.

In this paper we examine MNCs' foreign entry strategies making the distinction between market-seeking and strategic-resource seeking motivations of MNCs. However, we also use institutional lenses to embed the MNCs in the foreign environment. In this manner, we contribute for a better understanding of the determinants (institutional) and consequences (strategic choices) that are involved in $\mathrm{MNCs}$ ' foreign entry strategies. Hence, we expect to provide an additional perspective on foreign entry strategies and institutional theory beyond that recently developed by $\mathrm{Xu}$ and Shenkar (2002) and Kostova and Zaheer (1999). In fact, it is likely that, at 
least in some instances, the entry mode is not only a strategic response as was argued by Oliver (1997), neither seemingly wholly determined by the institutional environment where firms operate (DIMAGGIO; POWELL, 1983). The foreign entry modes selected may in actuality depend primarily on the a priori strategy of the MNCs. We focus specifically on the distinction between strategic-resource seeking and market seeking strategies in foreign operations because these two strategies highlight two contrasting uses and purposes of firm-specific assets.

Towards the purpose of examining how the firms' knowledge strategy (MARCH, 1991; TALLMAN; FLADMOE LINDQUIST, 2002) on foreign expansion influences the foreign entry strategies we also observe the institutional pressures impacting firms. Moreover, we consider three levels of analyses: host country, institutional distance between home and host country, and inter-firm interfaces. Thus, in this paper, we focus on the foreign entry strategies (knowledge and entry modes) and the institutional environment, with a special emphasis on how strategies may differ even in the presence of institutional pressures when the MNC pursues a market-seeking or a strategic-resource seeking strategy.

The remaining of this paper is organized in four three parts. In the first part, we briefly review the extant research on entry modes and institutional theory. In the second part we develop theory putting forward a set of propositions. We conclude the paper with a broad discussion, implications for theory and practice and advancing some avenues for future research.

\section{THEORY REVIEW}

In the following sections we briefly review the more relevant research on entry modes and institutional theory. The concepts and advancements presented feed the next section where we advance a set of propositions.

\section{The Foreign Entry Strategies}

Firms interested in serving foreign markets face a difficult decision in respect to the choice of entry mode (AGARWAL; RAMASWAMI, 1992). The extant research on the entry modes into foreign markets is quite vast in international business (IB) studies and an extensive review is not the goal of this paper. Notwithstanding, we may present the major developments by focusing on three main approaches that classify a large portion of the existing research. The first, is the process or stages model. This is rooted in the idea that firms internationalize first to countries with which the psychic distance is shorter, and using low involvement entry modes (e.g., exports) and that gradually expand their operations to more distant countries and 
utilizing higher involvement entry modes (JOHANSON; WIEDERSHIEM-PAUL, 1975; JOHANSON; VAHLNE, 1977; LUOSTARINEN; WELCH, 1990; ROOT, 1994). The research conducted by these authors, among others, suggests that foreign entry modes follow a sequential pattern that begins with exports and culminates with foreign direct investment (FDI) operations.

A second, approach sees entry modes into foreign markets as the result of market imperfections. In this view, the internalization by MNCs of market imperfections leads to their expansion abroad (see RUGMAN, 1981; TEECE, 1981; HENNART, 1982; WILLIAMSON, 1985; DUNNING, 1988; MARKINO; NEUPERT, 2000). The higher the market imperfection (e.g., market for knowledge) the more likely the MNC internalizes that market. This is, the larger the market imperfections the more likely MNCs will opt for entry modes of high involvement such as greenfield, acquisitions, or joint ventures (HENNART, 1982; ROOT, 1994; MARKINO; NEUPERT, 2000).

The third approach to foreign entry modes is based on a quasi-social networks perspective (ELLIS, 2000). This network approach suggests that MNCs' ties to other firms will be primary determinants of location and entry mode selection. In other words, business ties contribute to MNCs' internationalization by providing the MNC with information and opportunities (JOHANSON; MATTSON, 1988; ELLIS, 2000). For example, entry modes through cooperation (e.g., joint ventures) with other firms facilitates market entry, reduces risks and costs, and attenuates political and cultural constraints (STINCHCOMBE, 1965; ZAHEER, 1995; HENISZ, 2000).

This brief review on entry modes serves the purpose of establishing the possible modes of foreign involvement - or entry modes - that MNCs may select for each foreign market where they operate. We may classify the entry modes into: exports, licensing, joint ventures, strategic alliances, greenfield and acquisitions. Each mode's fit to the specific environment is also influenced by the strategy pursued, as we will discuss.

\section{The Institutional Theory in a Multinational Context}

Institutional theory adopts an open systems perspective whereby organizations are influenced by their environments. Described simply, the institutional environment influences will override an internal efficiency economic rationale for organization's choices (MEYER; ROWAN, 1977; DIMAGGIO; POWELL, 1983; OLIVER, 1991, 1997; XU; SHENKAR, 2002). The basic question that is asked by institutional theory is: why are organizations similar? Or, in other words, why do organizations adopt similar practices, procedures and structures? The simple answer is that organizations do so to increase their legitimacy and hence their changes of survival and growth. 
Legitimacy is, according to Meyer and Rowan (1977), a resource that may permit the firm to succeed (or not to fail). This means that legitimacy as a resource heightens the firms' ability to survive and access a variety of physical, financial, technical and social resources and to gain support from the audience (SUCHMAN, 1995).

The crux of institutional theory is that firms need to select appropriately the environments in which they operate, conform to those environments and, eventually, manipulate the environment in a manner that facilitates the organization to conform. For the MNCs and IB researchers it is therefore important to determine the factors that make the MNCs' actions and strategies legitimate or not. That is: firms need to understand how to achieve legitimacy or conformity.

It is likely that the entry mode into foreign countries is a primary determinant of the MNC (or subsidiary) legitimacy because the entry mode chosen reflects the degree of local embeddedness (e.g., ties to local firms in the case of a strategic alliance or joint venture), degree of adaptation of the products, and overall commitment to the host location (e.g., firms are more committed when they realize foreign investment in a greefield startup or an acquisition). In considering the legitimacy of the organization in its environment we need to consider what the MNCs can do to improve their "fit" with the environment. For example, MNCs that are engaged in quality controls, have a positive press coverage, support social causes, contract with consulting and accounting firms, commercialize high quality products, carry significant efforts in research and development, enter alliances with other well reputed firms in the industry or in a related industry, and so forth, are more likely to be legitimate.

Hence, to enhance its legitimacy, the MNCs may follow one of the three types of isomorphism described by DiMaggio and Powell (1983). First, the coercive isomorphism indicating that organizations adopt certain structures ad procedures because they are forced to do so. That is, there may be laws or local requirements (e.g., incorporation of locally produced content) that force firms to select some form of operation. Second, the normative isomorphism indicates that organizations adopt certain structures and procedures because these are assumed to be better than the alternatives. That is, MNCs conform to norms because these are norms of what should be done and lead to better outcomes in a certain market. Third, the firms may follow mimetic isomorphism which, in essence, indicates that firms imitate other firms because these are perceived to be successful or simply because of a high level of uncertainty regarding what are the best ways to organize and operate. In fact, the MNCs may gain legitimacy by following isomorphism choices. That is, MNCs adhere to norms, rules, procedures, and adopt organizational structures that increase their legitimacy. At least to some extent this involves being similar to other firms operating in the same location and/or industry. 


\section{THEORY DEVELOPMENT}

In this section we contribute to a better understanding of how firms deploy their strategies in the face of institutional constraints and opportunities. It seems reasonable to argue that the MNCs are subject to higher levels of structural (i.e., internal to the firm) and environmental (i.e., external and pertaining to the exterior) complexity than domestic firms (GUISINGER, 2001). This is reflected in the realms of institutional theory in the MNCs being constrained by the following four dimensions: (a) host country institutional environment (HENISZ, 2000; HENISZ; DELIOs, 2001), (b) home country institutional environment (which is important not only for the resources but also for institutional conditions, demand conditions, input conditions, level of rivalry among incumbent firms - see STINCHCOMBE, 1965; PORTER, 1990), (c) inter-firms' interfaces (i.e., relationships with, or simply the influence of, other firms) or mimicry (ZUCKER, 1987; DACIN, 1997), and (d) internal pressures (ZUCKER, 1987). Thus, we suggest that a more comprehensive examination of the impact of institutional factors on the entry modes selected benefits from observing these four levels of analysis complementarily. Given that each host country has a different set of rules, norm, and procedures firms need to adhere to idiosyncratic ceremonies. Each ceremony will also have different consequences on the strategic choices of the MNCs.

\section{The MNCs' Strategies: Leveraging and Augmenting Capabilities}

The last two decades have witnessed the emergence of a new perspective in IB studies focusing on the importance of learning and augmenting firms' capabilities (TALLMAN, 1991; DUNNING, 1993; BARKEMA; BELL; PENNINGS, 1996; GRANT, 1996). This perspective may be termed competence-, knowledge- (BARNEY, 1991; CONNER; PRAHALAD, 1996) or capabilities-based approach (TALLMAN; FLADMOE-LINDQUIST, 2002). Hence, firms not only expand abroad to exploit their capabilities seeking for markets where they are able to maintain a competitive advantage, following the more traditional stream of research in IB studies, but firms also seek to augment those capabilities (MARCH, 1991; TALLMAN, 1991; TALLMAN; FLADMOE LINDQUIST, 2002). It is now accepted that firms, namely the MNCs, compete primarily on the basis of the capabilities they hold. The strategic resource seeking strategies are receiving increased attention as firms shift focus from simply accessing local markets and natural resources to accessing to knowledge intensive assets (DUNNING, 1998) but also knowledge that is locationspecific. In sum, firms' strategies may be focused on market seeking or strategic resource seeking motivations (DUNNING, 1993; EDEN; MONTEILS, 2000). 
The purpose of a strategic resource seeking strategy is to learn from other firms and host countries. These assets, or resources, may take multiple forms: innovation capability, organizational capability, market penetration capability for accessing distribution channels and understanding the host countries consumers' tastes and preferences (DUNNING, 1993). Much of the capabilities are developed internally, as firms accumulate experience (NELSON; WINTER, 1982; FERREIRA, 2005) holding a tacit dimension that entails experiential learning.

In sum, while the traditionally considered purpose of foreign investment and foreign operations by MNCs has been the exploitation of an existing ownership advantage (DUNNING, 1993), more contemporary purposes include the protection of an existing advantage of the firm, or to develop new capabilities and advantages. Generally stated, firms' will be seeking novel knowledge in more developed countries.

\section{The Host Country Institutional Environment}

Institutional theory has frequently been interpreted as deterministic and as positing that an organization operating within an institutional context is powerless and compelled to conform to the pressures exerted upon it by the institutional environment (OLIVER 1991; DONALDSON, 1995). However, several authors (e.g., OLIVER, 1991; SUCHMAN, 1995) have been suggesting that firms may choose among a variety of responses and develop strategic responses tailored the specific institutional pressures (OLIVER, 1991; SUCHMAN, 1995) and these strategies provide different levels of legitimacy.

When firms operate in an host country they are at a disadvantageous position relative to home country firms (HYMER, 1976; ZAHEER, 1995). These are disadvantages relating to the lack of knowledge on the host country in such dimensions such as political, legal policies, social norms, customers preferences, and so forth. However, as foreign firms accumulate business experience and knowledge about the host market, they gradually develop the ability to operating in the host country (DUNNING, 1993; BARKEMA et al., 1996; GUISINGER, 2001). Moreover, at least to some extent, the level and form of commitment of the firm to the foreign country depends on the knowledge held of the host country. For instance, foreign MNCs may prefer to start foreign operations entering with some form of partnership (e.g., joint venture, strategic alliance) or with entry modes that require a lesser compromise of resources (e.g., exports, licensing). Later on, as firms consolidate foreign experience, they may consider more reasonable to develop their foreign operations using models such as greenfield investments or acquisitions of incumbent firms (KUMAR \& SUBRAMAINAM, 1997; MARKINO \& NEUPERT, 2000; CHANG \& ROSEINZWEIG; 2001). 
The institutional characteristics of the host country are likely to influence the choice of the entry mode in foreign countries. Developed institutional environments (both regulatively and normatively) tend to be typical of more developed countries (HENISZ, 2000). Developed countries have well established institutions that guarantee the enforceability of contracts, and generally reduce transaction hazards and opportunistic behaviors (WILLIAMSON, 1985). Less developed countries lack reliable business information systems, established institutions to support business activities and an effective institutional setting to enforce contracts (KHANNA; PALEPU, 1997) that makes transactions costly and creates uncertainty. Therefore, concerns related to the appropriability of the returns from innovative efforts, risks of reverse engineering, illegal copying of software and other forms of intellectual property, are less likely in more developed countries. For MNCs pursuing a market-seeking strategy, this implies that they may commercialize at a distance without concerns for illegal or hazardous appropriation of their returns by third parties. That is, firms may deploy exports as the entry mode. In addition, the enforceability of contracts also guarantees that the contracts for licensing agreements will tend to be honored, avoiding legal incursions and penalties. In sum, the opportunities presented by those developed countries may be exploited by leveraging the MNCs' capabilities in the host market.

Conversely, the MNCs pursuing strategic resource seeking strategies in the host foreign country are likely to be exposed to a different set of institutional pressures. These pressures may accrue on regulative, cognitive and normative forms. It seems reasonable to suggest that the concern for the MNCs pursuing a strategic resource seeking will be based on the processes that will allow them to become more embedded in the local milieu. That is because local embeddedness is likely to facilitate the inflow of knowledge (i.e., learning) that the MNCs are aiming for (BARKEMA et al., 1996). Hence, by conforming to the host country norms and practices the foreign MNCs are taken as insiders rather than outsiders and thus will likely have easier access to local knowledge and other locally-based strategic assets. This seems consistent with the current growth of alliances in the western countries (DUNNING, 1993).

The strategic impetus - in this paper subsumed to the distinction between strategic resource seeking and market seeking - is important for the choice of entry mode. Note, for example, that Henisz and Delios (2001) suggested that MNCs seem to seek JVs when entering more unstable environments. In this reasoning it seems that market seeking and strategic resource seeking entries should provide different predictions regarding foreign market entry modes.

Proposition 1a. The MNCs following a strategic resource seeking strategy entering more institutionally developed foreign markets will tend to use joint ventures and acquisitions as opposed to greenfield and exports entry modes. 
Proposition 1b. The MNCs following a market seeking strategy entering more institutionally developed foreign markets will tend to use exports, licensing and greenfield as opposed to joint ventures and acquisitions entry modes.

\section{Institutional Distance}

While the static analysis of home country institutional factors may not be peculiarly interesting, the analysis of institutional distance, or differences, between home and host country is most relevant. The home country will imprint (STINCHCOMBE, 1965) the MNC from inception and therefore the womb in which the MNC is born will be determinant throughout its existence. The distance between home and host country has made some inroads in IB studies but mainly through the work on cultural distance (HOFSTEDE, 1980; KOGUT; SINGHT, 1988) and psychic distance (JOHANSON; VAHLNE, 1977). Notwithstanding, some studies have specifically addressed institutional distance, such as Kostova and Zaheer (1999), Xu and Shenkar (2002). These studies point out that larger institutional distance between countries will create difficulties in the operation of the MNC. In face of these difficulties, that emerge from differences in practices, norms, procedure, rules, and so forth, and are fueled by impairment of cognition at the managerial level, it is likely that MNCs will chose foreign entry modes that require low involvement (e.g., exports) rather that a large commitment of resources (e.g., acquisition). That is because larger distances also entail more uncertainty and risk. Xu and Shenkar (2002) noted the different impact of the institutional dimensions when the institutional distance is larger. However, these authors seem to have assumed the traditional market seeking perspective on foreign operations, disregarding a strategic resource seeking motivation. It is probable that MNCs pursuing a strategic resource seeking strategy will be affected by institutional distance at least in a different manner.

An MNC pursuing a strategic resource seeking strategy may engage in different strategic choices regarding entry mode. This is because larger distance also signifies that the technological path of the country has been more different (KOGUT, 1991; CANTWELL, 2001). Therefore it is likely that the stock of knowledge and technologies held by local firms is most different from those already absorbed by the MNC (COHEN; LEVINTHAL, 1990) in the home country and in other locations. In this regard, under a strategic resource seeking strategy, the MNC will most likely attempt to tap into this local pool of different knowledge in a manner that guarantees most conformity and local embeddedness as a manner to guarantee the best access to the local strategic assets. Therefore, while a market seeking strategy might advise a low involvement mode (e.g., XU; SHENKAR, 2002), a strategic resource seeking strategy may advise a high commitment entry mode. The former may be realized through joint ventures and/or acquisition of an incumbent firm. 
The business environments of developed and less develop countries do differ in a number of dimensions, such as culture, norms and procedures, economic and legal systems and business routines. These differences amplify the perceived distance and between the home and the host market and the perceived risks with unfamiliar locations (HILL; HWANG; KIM, 1990; HENNART; LARIMO, 1998). To some extent, the environment in developing countries is more complex than that in developed countries, given the institutional inefectiveness and the well known transaction hazard. In these instances, managing a joint venture, an alliance or even a partial equity stake in an acquisition in developed countries is easier than that in less developed countries (BEAMISH, 1985). Moreover, the distance per se also influences firms' choices. Makino and Neupert (2000), for example, found that US firms investing in Japan were more likely to prefer joint ventures over wholly-owned subsidiaries.

However, a note of caution needs to be made because distance may not be symmetrical. This is, MNCs' strategies are likely vary if the MNC is entering an institutionally distant country but still a more institutionalized country, than if the entry is into a distant country but a less institutionalized country. Therefore, we need to consider the degree of the institutionalization of the host country. That is to say that strategic resource seeking investments flow essentially among highly institutionalized and developed countries (e.g., US <-> Western Europe) and from less developed to more developed countries. Although in some instances MNCs may seek novel knowledge (in a strategic asset-seeking rationale) in less developed countries, this is not likely to be an usual search (although research in industry clusters has some examples of locations of excellence in less developed countries). Notwithstanding, we propose that:

Proposition 2a. The MNCs following a market seeking strategy from less institutionally developed countries entering institutionally distant countries (i.e., more institutionalized) will tend to use exports, licensing and greenfield as opposed to joint ventures and acquisitions as the entry modes.

Proposition $2 \boldsymbol{b}$. The MNCs following a strategic resource seeking strategy from less institutionally developed countries entering institutionally distant countries (i.e., more institutionalized) will tend to through joint ventures and acquisitions as opposed to exports, licensing and greenfield as the entry modes.

Proposition 2c. The MNCs following a market seeking strategy from more institutionally developed countries entering institutionally distant countries (i.e., less institutionally developed) will tend to use exports and minority joint ventures as opposed to greenfield and acquisitions as the entry modes.

Inter-firm Interfaces and Mimicry

When entering a foreign market, the MNCs are likely to adopt imitation strategies because of the high environmental complexity (GUISINGER, 2001), volatil- 
ity (DUNNING, 1995), need for flexible models (BUCKLEY; CASSON, 1998). Haveman (1994) enunciated the manners in which one organization may come to mimetically follow other (i.e., mimetic isomorphism). In general, MNCs have four possible main groups of referents for imitation choices. First, MNCs may imitate firms that are in the same industry. These firms tend to be more readily identified and are more salient to the focal MNC. Therefore, these firms are more easily understood and their strategies more easily followed. Second, imitate firms that appear to be more successful. One of the main reasons for imitation is to overcome uncertainty, and the imitation of a successful firm allows an easier (not necessarily easy because of causal ambiguity - see, for example, REED; DEFILLIPPI, 1990) identification of the appropriate norms, procedures and structures. Third, MNCs may imitate large firms. A large firm may be a good referent given that one of the objectives of the focal MNC may be growth. Notwithstanding, we note that the imitation of a large firm may be more complex and ambiguous because a large firm may possess slack resources and/or be able to hide its failures for a long period of time covert by a long term strategy. While MNCs tend to be large firms, that is not necessarily the case (OVIATT; MCDOUGAL, 1994). Fourth, MNCs may imitate firms of similar size. This is because these firms are more likely to have similar levels of utilized and slack resources, similar organizational structures, similar strategies and similar constraints. Finally, MNCs may follow the leader firm either in the host or in the home country. This may have some parallelism with the 'oligopolistic reaction' observed by international business scholars (KNICKERBOCKER, 1973). Haveman (1994) suggested that firms tend to mimic other firms in geographically proximate locations. This suggests either firms in the home (more proximate) or host countries, but less likely third country firms.

The analysis of inter-firm interface (i.e., relationships of the focal MNC with other firms) is quite complex and is probably tied to mimicking behaviors. This suggests an uncertainty reduction strategy in what seems to be an overt utilization of referent others (HAVEMAN, 1994; SHAH, 1998). It is not easily discernible who the MNCs will imitate to operate in a host market, neither what are the implications for the MNC. Clearly, the arguments for imitation of similar firms have been advanced by scholars such as Knickerbocker (1973) and Haveman (1994), and might be possible that MNCs will tend to mimic firms from the same home country. Only in the absence of a home country referent would the MNCs look beyond borders for a referent other. However, it is uncertain under which conditions will the imitation of other firm occur. In specific, it seems reasonable to suggest that the mimicking effects will be different for MNCs pursuing a market seeking strategy from those of MNCs pursuing a strategy-resource seeking strategy for their foreign operations. Or, in other words, it is unclear whom the MNC uses as referent since the best choice is 
likely to vary according to whether the MNC is following a market seeking strategy or a strategic resource seeking strategy.

For instance, a market seeking MNC is likely to look at successful competing firms regardless of their nationality, or country origin, insofar as this referent appears to be particularly successful in the host market. A market seeking strategy envisions just that, the successful commercialization. Hence, MNCs seeking to enlarge their market need to show some conformity to the local normative and respect the regulatory aspects of operating in the host market. However, these MNCs need to maintain some flexibility to exploit their capabilities in the host market. In this case, what seems important is to look after the key aspects of operating in the market and any seemingly successful firm provides the insights required. The imitation of other foreign firms pursuing a similar goal is a reasonable action.

Conversely, it seems reasonable to suggest that a strategic resource seeking MNC might have a different set of referent others. The strategic resource seeking MNCs may chose to mimic a local firm that is particularly well embedded in the local environment and perhaps that is highly innovative. In fact, the mimicry of a local firm seeks for a better fit within the local environment to guarantee access to the key players. Hence, MNCs seeking to augment their own resources and capabilities may be more sensitive to conformity to host market conditions and hence use host country firms as referents. It is reasonable to suggest that this is the solution to access knowledge held by local firms or knowledge that is location-specific.

The distinction between market-seeking and strategic market seeking is mainly on the form of who does the MNC consider as successful given a certain set of goals. But, in any case it is likely that it will have an impact on the entry strategy in terms of imitation. In terms of specific predictions, this is a case where a general proposition may be formulated for both market and strategic resource seeking MNCs.

Proposition 3a. The MNCs following a market seeking strategy will tend to enter foreign countries through entry modes most similar to successful leading home or third country firms.

Proposition 3b. The MNCs following a strategic resource seeking strategy will tend to enter foreign countries through entry modes that permit most similarity to the success factors of leading referent host country firms.

\section{DISCUSSION AND CONCLUDING REMARKS}

Although we leave unattended to several avenues and possibly interesting propositions that could be tested, this paper advances over existing research in multiple ways. The consideration of the four levels (i.e. internal, home, host and inter-firm) of 
analysis is also interesting because it represents a more accurate representation of the pressures that the MNC faces. The distinction between market-seeking investments and strategic resource seeking investments is worth being further studied. It is likely that the strategic choices of the MNC are likely to be influenced by the institutional environment but the strategy is also a materialization of the firm's cognition. The inclusion of the MNC international experience as a moderator, reinforces existing research on learning in an experiential manner (BARKEMA et al., 1996).

The MNCs engage in market seeking foreign operations to capture clients in foreign countries. These operations are based on the exploitation of the capabilities and knowledge already held. Conversely, the MNCs engage in strategic resource seeking foreign operations to capture new knowledge, technologies, innovations, business processes and so forth. The strategic resource seeking foreign investment operations are influenced by the choice of locations and firms need to assess whether the host country provides access to the knowledge-related resources desired, but also to the institutional aspects that may facilitate or hinder the firms from capturing those assets (DUNNING, 1998). The choice of the entry mode into those foreign markets needs to be adapted to the characteristics of those markets to facilitate the capture of the strategic resources that are being sought after.

Future research may proceed in a number of ways. In this paper we did not delve into the internal pressures towards conformity, which are likely to bear significant impact on the choice of entry modes. Indeed it may be reasonable to suggest that the internal pressures impacts on the ability of the firm to pursue strategic resource seeking foreign entry modes. Hence, we may expect strategic resource seeking MNCS to be more flexible to different forms. This is to say that internal isomorphic pressures are likely to be near negligible under a strategic resource seeking strategy. Conversely, these internal pressures are likely to be near insurmountable for MNCs pursuing market-seeking strategies. Suffice is to note that strategic resource seeking strategies entail exploration (MARCH, 1991) and that market-seeking entail the exploitation of the focal MNC's resources, capabilities, routines (NELSON \& WINTER, 1982; BARNEY, 1991, TEECE, PISANO \& SHUEN, 1997, TRIPSAS, 1997). In this regard market-seeking strategies need to abide by the internal norms and procedures to exploit ownership-specific advantages (DUNNING, 1977, 1998) abroad. In this vein, future research may explore whether the MNCs pursuing strategic resource seeking strategies are more or less likely than MNCs pursuing market-seeking strategies to face the need to conform to internal isomorphic pressures. And, specifically, whether the MNCs will tend to enter foreign countries through joint ventures and acquisitions when following a strategic resource seeking strategy.

Although we introduced some complexity in our conceptualizations, by considering three main dimensions: entry modes, international strategy and institutional 
environment pressures, there are many other factors that need to be taken into account. For instance, there may exist industry specific factors affecting both the strategy and the entry modes. Scherer and Ross (1990) suggest that firms in industries requiring large investment with high asset specificity to the host country, the MNC that is market seeking is likely to choose entering through full ownership modes such as wholly owned greenfield or acquisitions.

Future research may further seek to test empirically the propositions we formulated. Empirical tests may be based on both primary data (collected through a survey to MNCs) and secondary data to measure specific environmental dimensions (e.g., Witold Henisz's Political economy database, World Bank, United Nations, etc.).

For researchers in international business and strategic management studies our paper proposes that it is important to make a more comprehensive examination of the conditions under which specific choices are made. For practitioners, we advance the need to consider the environmental pressures and observe whether specific strategies might be viable. While the objectives of operating in a certain foreign market may be clear, the specific manner in which they are accomplished may vary drastically. Some foreign entry modes are better for specific purposes but it depends on the markets being entered. A prescriptive framework of foreign entry modes does not exist.

To conclude, the MNCs' market or resource seeking strategies are deployed in specific foreign entry modes but not in atomistic manner, rather we need to observe the idiosyncrasies of the host market and the overall operations of the MNCs.

\section{REFERENCES}

AGARWAL, S.; RAMASWAMI, S. Choice of foreign market entry mode: Impact of ownership, location, and internalization factors. Journal of International Business Studies, v. 23 (First Quarter), p. 1-27, 1992.

BARKEMA, H.; BELL, J.; PENNINGS, J. Foreign entry, cultural barriers, and learning. Strategic Management Journal, v. 17, p. 151-166, 1996.

BARNEY, J. Firm resources and sustained competitive advantage, Journal of Management, v. 17 (1), p. 99-120, 1991.

BEAMISH, P. The characteristics of joint venture in developed and developing countries. Columbia Journal of World Business, Fall, p. 13-19, 1985.

BUCKLEY, P.; CASSON, M. Models of the multinational enterprise, Journal of International Business Studies, v. 29, n. 1, p. 21-44, 1998. 
CANTWELL, J. Innovation and information technology in MNE, in Rugman, A. \& Brewer, T. (Eds.). Oxford Handbook of International Business. Oxford University Press, Oxford, 2001.

CHANG, S.; ROSEINZWEIG, P. The choice of entry mode in sequential foreign direct investment. Strategic Management Journal, v. 22, n. 8, p. 483-497, 2001.

COHEN, W.; LEVINTHAL, D. Absorptive capacity: A new perspective on learning and innovation. Administrative Science Quarterly, v. 35, p. 128-152, 1990.

CONNER, K.; PRAHALAD, C. A resource-based theory of the firm: Knowledge versus opportunism. Organization Science, v. 7, n. 5, p. 477-501, 1996.

DACIN, M. Isomorphism in context: The power and prescription of institutional norms. Academy of Management Journal, v. 40, n. 1, p. 46-81, 1997.

DIMAGGIO, P.; POWELL, W. The iron cage revisited: Institutional isomorphism and collective rationality in organizational fields. American Sociological Review, v. 48, n. 2 , p. 147-160, 1983.

DONALDSON, L. American anti-management theories of organization: A critique of paradigm proliferation. New York: Cambridge University Press, 1995.

DUNNING, J. The location of economic activity and the multinational enterprise: A search for an eclectic approach. In Ohlin, B., Hesselborn, P. and Wilkman, P. (Eds) The international allocation of economic activity, London: Macmillan, 1977.

DUNNING, J. The eclectic paradigm of international production: A restatement and some possible extensions. Journal of International Business Studies, Spring, p. 1-31, 1988 .

DUNNING, J. Multinational enterprises and the global economy. Addison-Wesley Publishing Company, 1993.

DUNNING, J. Reappraising the eclectic paradigm in an age of alliance capitalism. Journal of International Business Studies, Third quarter, p. 461-491, 1995.

DUNNING, J. Location and the multinational enterprise: A neglected factor? Journal of International Business Studies. V. 29, n. 1, p. 45-66, 1998.

ELLIS, P. Social ties and foreign market entry. Journal of International Business Studies, v. 31, p. 443-469, 2000. 
FERREIRA, M. The effect of the MNC's capabilities and knowledge strategy on the degree of equity ownership acquired. Unpublished doctoral dissertation, The University of Utah, USA, 2005.

GRANT, R. The resource-based theory of competitive advantage: Implications for strategy formulation. California Management Review, 1991.

GRANT, R. Toward a knowledge-based theory of the firm. Strategic Management Journal, v. 17 (Winter Special Issue), p. 109-122, 1996.

GUISINGER, S. From OLI to OLMA: Incorporating higher levels of environmental and structural complexity into the Eclectic paradigm. International Journal of the Economics of Business, v. 8, n. 2, p. 257-272, 2001.

HAVEMAN, H. Follow the leader: Mimetic isomorphism and entry into new markets. Administrative Science Quarterly, v. 38, p. 593-627, 1994.

HENISZ, W.; DELIOS, A. Uncertainty, imitation and plant location: Japanese multinational corporations, 1990-96", Administrative Science Quarterly, v. 46, n. 3, p.443-475, 2001.

HENISZ, W. The institutional environment for multinational investment, Journal of Law, Economics and Organization, v. 16, n. 2, p.334-364, 2000.

HENNART, J-F.; LARIMO, J. The impact of culture on the strategy of multinational enterprises: Does national origin affect ownership decisions? Journal of International Business Studies, v. 29, n. 3, p. 515-538, 1998.

HENNART, J-F. A theory of the multinational enterprise. University of Michigan Press, Ann Arbor, MI, 1982.

HILL, C.; HWANG, P.;; KIM, C. An eclectic theory of the choice of international entry mode, Strategic Management Journal, v. 11, n. 2, p. 117-128, 1990.

HOFSTEDE, G. Culture's consequences: International differences in workrelated values. Beverly Hills, CA: Sage Publications, 1980.

HYMER, S. The international operations of national firms: A study of direct foreign investment. Cambridge, Mass.: MIT Press, 1976.

JOHANSON, J.; J-E. VAHLNE. The internationalization process of the firm: A model of knowledge and increasing foreign market commitments (1977). In Buckley, 
Foreign entry modes under institutional pressures: the impact of strategic resource seeking and market seeking strategies

Peter J. \& Ghauri, Pervez (Eds). The internationalization of the firm. London, p. 32-44, 1994

JOHANSON, J. ; MATTSSON, L-G. Internationalization in Industrial Systems- a Network Approach (1988). In Buckley, Peter J. \& Ghauri, Pervez. The internationalization of the firm. London, p. 303-321, 1994.

JOHANSON, J.; WIEDERSHEIM-PAUL, F. The internationalization of the firm: Four swedish cases. (1975). In Buckley, P. \& Ghauri, P. (Eds.) The internationalization of the firm. London, p. 16-31, 1994

KANTER, R. The institutional perspective on management. Harvard Business Review. May, 1997.

KHANNA, T.; PALEPU, K. Why focused strategies may be wrong for emerging markets, Harvard Business Review, v. 75, n. 4, p. 41-51, 1997.

Knickerbocker, F. Oligopolistic reaction and multinational enterprise. Cambridge, MA: Harvard University Press, 1973.

KOGUT, B.; SINGH, H. The effect of national culture on the choice of entry mode. Journal of International Business Studies. Fall, p. 411-432, 1988.

KOGUT, B. Joint ventures: Theoretical and empirical perspectives. Strategic Management Journal, v. 9, p. 319-332, 1988.

KOGUT, B. Country capabilities and the permeability of borders. Strategic Management Journal, v. 12 (Summer), p. 33-47, 1991.

KOSTOVA, T.; ZAHEER, S. Organizational legitimacy under conditions of complexity: The case of the multinational enterprise. Academy of Management Review, v. 24, n. 1, p. 64-81, 1999.

KUMAR, V.; SUBRAMAINAM, V. A contingency framework for the mode of entry decision. Journal of world Business, v. 32, n. 1, p. 53-72, 1997.

LUOSTARINEN, R.; WELCH, L. International business operations. Finland, Helsinki School of Economics, 1990.

MAKINO, S.; NEUPERT, K. National culture, transaction costs, and the choice between joint venture and wholly owned subsidiary. Journal of International Business Studies, v. 31, p. 705-713, 2000. 
MARCH, J. Exploration and exploitation in organizational learning. Organization Science, v. 2, n. 1, p. 71-87, 1991.

MCKELVEY, B. Quasi-natural organization science. Organization Science, v. 8, p. 352-380, 1997.

MEYER, J.; ROWAN, B. Institutional organizations: Formal structure as myth and ceremony. American Journal of Sociology, v. 83, p. 340-363, 1977.

NELSON, R.; WINTER, S. An evolutionary theory of economic change. Belknap Harvard, 1982

OLIVER, C. Strategic responses to institutional processes. Academy of Management Review, v. 16, n. 1, p. 145-179, 1991.

OLIVER, C. The influence of institutional and task environment relationship on organizational performance. Journal of Management Studies, v. 34, n. 1, p. 99-124, 1997.

OVIATT; MCDOUGAL, P. Toward a theory of international new ventures. Journal of International Business Studies, First quarter, p. 45-64, 1994.

Porter, M. The competitive advantage of nations. New York: Free Press, 1990.

REED, R.; DEFILLIPI, R. Causal ambiguity, barriers to imitation, and sustainable competitive advantage. Academy of Management Review, v. 15, n. 1, p. 88-102, 1990.

ROOT, F. Entry strategies for international markets. Lexington Books. 1994.

RUGMAN, A. Inside the multinationals: The economics of internal markets. London: Croom Helm, 1981.

SCHERER, F.; ROSS, D. Industrial market structure and economic performance, Houghton and Mifflin Company, Boston, 1990.

SHAH, P. Who are employees' social referents? Using a network perspective to determine referent others. Academy of Management Journal, v. 41, n. 3, p. 249-268, 1988.

STINCHCOMBE, A. Social structure and organizations. In March, James (Ed.) Handbook of Organizations, Chicago, IL: Rand McNally, p. 153-193, 1965. 
Foreign entry modes under institutional pressures: the impact of strategic resource seeking and market seeking strategies

SUCHMAN, M. Managing legitimacy: Strategic and institutional approaches. Academy of Management Review, v. 20, n. 3, p. 517-610, 1995.

TALLMAN, S.; FLADMOE-LINDQUIST, K. Internationalization, globalization, and capability-based strategy. California Management Review, v. 45, n. 1, p. 116-135, 2001.

TALLMAN, S. Strategic management models and resource-based strategies among MNE's in a host market. Strategic Management Journal, v. 12, p. 69-82, 1991.

TEECE, D. The multinational enterprise: Market failure and market power considerations. Sloan Management Review, v. 22, p. 3-17, 1981.

TEECE, D.; PISANO, G.; SHUEN, A. Dynamic capabilities and strategic management. Strategic Management Journal, v. 18, n. 7, p. 509-533, 1997.

TRIPSAS, M. Unraveling the process of creative destruction: Complementary assets and incumbent survival in the typesetter industry. Strategic Management Journal, v. 18 (special issue), p.119-142, 1997.

WILLIAMSON, O. The economic institutions of capitalism: firms, markets, relational contracting. New York: Free Press, 1985.

XU, D.; SHENKAR, O. Institutional distance and the multinational enterprise. Academy of Management Review, v. 27, n. 4, p. 608-618, 2002.

ZAHEER, S. Overcoming the liability of foreignness. Academy of Management Journal, v. 38, n. 2, p. 341-363, 1995.

ZUCKER, L. Institutional theories of organization. Annual Review of Sociology, v. 13, p. 443-464, 1987. 